\title{
Critical Factors Underlying Students' Choice of Institution for Graduate Programmes: Empirical Evidence from Ghana
}

\author{
Joseph Mbawuni ${ }^{1} \&$ Simon Gyasi Nimako ${ }^{2}$ \\ ${ }^{1}$ Faculty of Business Education, University of Education, Winneba, Ghana \\ ${ }^{2}$ Department of Management Studies, University of Education, Winneba, Ghana \\ Correspondence: Joseph Mbawuni, Faculty of Business Education, University of Education, Winneba, Ghana. E-mail: \\ mbawuni@gmail.com
}

Received: December 16, 2014

Accepted: January 6, $2015 \quad$ Online Published: January 10, 2015

doi:10.5430/ijhe.v4n1p120

URL: http://dx.doi.org/10.5430/ijhe.v4n1p120

\begin{abstract}
The growth in higher education industry has caused a tremendous increase in the number and type of colleges, polytechnics and universities offering similar academic programmes especially in business disciplines in Ghana. The resultant competition in the education industry makes it crucial for education managers to understand the latent factors that underlie students' college and programme selection. The purpose of this study was to explore the factors underlying students' choices in accessing higher education in Ghana. The study was a cross-sectional survey of 183 students offering different masters' programmes in a public university in Ghana. It utilized exploratory factor analysis to identify seven latent factors that play critical role in students' choice of master's programmes. These factors are cost, student support quality, attachment to institution, recommendation from lecturers and other staff, failure to gain alternative admissions, location benefits, among others. The results of this research are beneficial to both scholars and management of colleges in the development of competitive advantage and appropriate promotional strategies for college and academic programmes that appeal favourably to potential students than competitors in Ghana and other developing countries. The paper contributes to the literature in the area of access and management of higher education.
\end{abstract}

Keywords: Factor analysis, Students' choices, Higher Education

\section{Introduction}

Higher educational institutions (HEIs) fundamentally provide the opportunity for students to advance their academic careers and to achieve desired professional development. The choice of programmes in general and graduate programmes in particular in higher education institutions (HEIs) is an important issue of consideration, and yet it remains a dilemma for most students (Beggs, Bantham, \& Taylor, 2008; Briggs, \& Wilson, 2007; Ming, 2010; Paulsen \& St John, 2002).

In Sub Saharan Africa (SSA) in general and Ghana in particular, the increase in demand and supply of HEIs is felt more than ever. HEIs in Ghana offer academic programmes that lead to the award of bachelors', masters' and doctorate degrees. Until the beginning of the twenty-first century these HEIs were predominantly public (government) owned. Although some new public HEIs such as the University of Energy and Natural Resources and the University of Health and Allied Sciences have been added in recent times, the growth of privately owned HEIs has been profound since early 2000. As of the beginning of 2014, Ghana had 76 accredited HEIs running various degree programmes, of which 21 were public institutions and 55 privately owned (National Accreditation Board, 2014). With about 71 of the 76 HEIs in Ghana running programmes in business related areas, there are more avenues for students to choose from which HEIs they want to obtain their master's programme. Most business schools and universities offer very similar degree programmes at the undergraduate and post-graduate levels. Recently some eight polytechnics begun offering degree programmes. This has further increased the intensity of competition for students in HEIs in Ghana (National Accreditation Board, 2014). It is increasingly becoming crucial for management of HEIs in SSA in general and Ghana in particular to understand the context- specific variables that strongly influence students' choice of programmes of studies in HEIs. This will provide school management with empirical information as feedback for developing effective management strategies for attracting and retaining local and international students. 
Apart from the need to inform managerial policy and strategy, the limitation in existing education literature also necessitates this research. Much of our understanding in college choice factors has been enhanced by research conducted in developed countries (e.g., Briggs, \& Wilson, 2007; Nurnberg, Schapiro, \& Zimmerman, 2012; Liu, 2005; Vrontis, Thrassou, \& Melanthiou, 2007; Wilkins, Shams, \& Huisman, 2013). In this regard, Liu (2005) observed that, "Most of the studies in college choice were conducted in the United States, Australia and some European countries" (p. 18). Empirical research in student college choice factors is limited in developing countries in general (e.g. Ming, 2010; Sidin, Hussin, \& Soon, 2003; bin Khairani, \& Razak, 2013), and in particular Sub-Saharan Africa (SSA). Therefore, more research is needed to understand factors that underpin students' choice of colleges and programmes of studies in HEIs in the SSA context. Therefore, the main purpose of this paper is to identify the latent variables underlying students' choice of HEI for masters' programmes in SSA, using Ghana as the research context. The main contribution of this paper is to extend empirical research on relevant factors underlying students' choice of college programmes to a developing country SSA perspective, in order to contribute to the literature in higher education management in developing countries. It provides evidence-based information for scholars and practitioners, especially in education leadership and management, towards developing competitive strategies for managing student enrolment and retention in HEI in general and SSA context in particular.

\section{Literature Review and Conceptual Framework}

\subsection{Theoretical models for explaining choice of HEI}

Choice of HEI is defined as "a complex, multistage process during which an individual develops aspirations to continue formal education beyond high school, followed later by a decision to attend a specific college, university or institution of advanced vocational training" (Hossler, Braxton, \& Coopersmith, 1989, p. 234). Since the 1970s, the subject of student choice of HEI has received a lot of attention. Proposed models of choice of HEI can be classified into four categories: (1) econometric models, (2) status-attainment models, (3) information -processing models, and (4) combined models (Hossler, Schmit, \& Vesper, 1999, pp. 141-142).

\subsubsection{Econometric models}

The fundamental notion underlying econometric (or economic) models for explaining choice of HEI is that students maximize a utility (e.g., high quality, low cost), often using cost-benefit analysis (Hossler et al., 1999, p. 142). The econometric model assumes that in the choice process, students consider the pros and cons of each, associate a utility or a value with the attributes of each, make reasonable assumptions about the outcomes of one decision over another, and then choose more or less rationally in order to maximize benefits and reduce costs (Hossler et al., 1999, p. 142). Two main branches of econometric models of college choice exist. The first expresses institutional or national enrollments as a function of characteristics of potential enrollees and existing schools (Vrontis et al., 2007). The second explains enrollment decision of an individual student as his revealed preference among the available schooling and work alternatives. The second branch puts the focus on the individual student rather than the institutions.

\subsubsection{Status-Attainment models}

Status-Attainment (or sociological) models assume a utilitarian decision-making process that students go through in choosing a college, specifying a variety of social and individual factors leading to occupational and educational aspirations (Jackson, 1982). The status-attainment models emphasize how socialization processes, family conditions, interactions with peers, and school environments help shape students' college choices (Hossler et al., 1999, p. 144). While econometric models assume that students make rational decisions, status-attainment models have more interaction between variables that measure the traits of individual students and variables that assess broad social constructs (Hossler et al., 1999, p. 144). The behavioral variables of students such as students' academic performance interact with background variables (such as the social status of parents) to determine students' educational aspirations (Briggs, 2006; Kallio, 1995; Paulsen \& St John, 2002).

\subsubsection{Combined models}

The combined models incorporate the rational assumptions in the economic models and components of the status attainment models. Most combined models divide the student decision-making process into three phases: aspirations development and alternative evaluation; options consideration; and evaluation of the remaining options and final decision (Jackson, 1982; Vrontis et al., 2007). Combined models have the distinct advantage in that the researcher can choose variables from either domains and concentrate on the sociological aspect of college choice as a process while maintaining the decision-making perspective of economics. Combined models may provide more explanatory power than any single perspective (Hossler et al., 1999; Vrontis et al., 2007). 


\subsubsection{The Jackson Three-Phase model}

The Jackson model involves three phases: preference, exclusion, and evaluation. Jackson (1982) proposes that a student goes through three stages prior to making a choice. In the first stage, that is the preference stage, Jackson shows academic achievement has the strongest correlation with students' educational aspirations. Family background and the student's social context influence these aspirations. In the second stage the student goes through a process of excluding some institutions from the prospective list. The resources available to the student affect these exclusions. Some factors that could result in the exclusion of a potential HEI may be tuition fees, location, or academic quality. After having made these exclusions, the student limits his/her choice and forms a choice set. Appreciating the fact that students do not always behave in a rational manner, Jackson went ahead to complete the model with the final stage being the evaluation stage which is made up of the rating scheme leading to the final choice.

\subsubsection{The Chapman model}

Chapman (1984) proposes that a student's general expectation of college life is formed when various student characteristics, such as socio-economic status and scholastic aptitude, interact with external influences from significant others or college characteristics. Chapman explains the choice as being a model of two stages - that of the pre-search and search stage. In the first stage, factors like family income have a direct effect on which colleges are considered. In addition, students appear to favour colleges that enroll students with academic ability similar to their own. During the second stage, the search stage, students gather information about specific institutions and make their final choice based on some favourable institutional characteristics.

\subsubsection{The Hanson and Litten model}

One of the models which contributes the most to the literature of college choice is that of Hanson and Litten (Hanson \& Litten, 1982). Similar to other models, the first stage of this three-stage model suggests that a student initially decides to participate in postsecondary education. During the second stage, the student investigates institutions and creates a set of candidates. The process of applying to an HEI and enrolling is the last stage. Within these three stages, there exist five distinct processes that a student passes through: having college aspirations; starting the search process; gathering information; sending applications; and enrolling. This five-step process introduced by Hanson and Litten shows multiple variables which affect college choice. Race and family culture, quality and social composition of high school, parents and counselors, self-image and personality, economic conditions of the environment, financial aid available, recruitment activities of colleges, size and programs of colleges, are just a few of these variables. The Hanson and Litten model is a cross between Jackson's student-based model and the more institution-based Chapman model (Hanson \& Litten, 1982)

\subsubsection{Information-Processing Models of College Choice}

Information-processing has been suggested as another perspective from which to examine the college selection process, especially the search stage (Hossler et al., 1999, p. 150). It makes gathering and processing information in a social setting an essential part of decision making. These models consider aspects of decision-making theory and sociology, especially social capital and socialization. Information processing, social capital and cultural capital together allow us to introduce into the choice process dynamic roles for parents, peers, and schools (Briggs, 2006; Kallio, 1995; Vrontis et al., 2007)

\subsection{Factors affecting Students' Choice of HEIs for Graduate Progarmmes}

Kallio (1995) examined the relative influence of factors affecting the college choice decisions of graduate students at a major research university. Through factor analysis and regression approaches, the author found several important factors that influence college choice decisions such as residency status, quality and other academic environment characteristics, work-related concerns, spouse considerations, financial aid, and the campus social environment. Zimmerman et al. (2000) has identified "push and pull" factors which operate along the students' decision-making process in the global market.

Ellwood and Kane (2000) found significant correlation between family income and enrollment in college within 20 months of graduating from high school, after controlling for measures of academic ability and achievement, tuition and financial aid, and tastes (measured by parental education). Terenzini, Cabrera, and Bernal (2001) studied college choice factors affecting students with low socio-economic status (SES) in America. Their study indicated that students with low SES affected low levels of income, typically from family income; they find it difficult paying tuition fees and lack financial aid for enrollment in colleges of their choice.

Sidin, Hussin, and Soon (2003) found that in Malaysia, students' selection of colleges actually depends on academic quality, facilities, campus surroundings, and personal characteristics, inter alia. Their results also support the assertion that income affects the choice of students along the public-private education divide. 
Dreher and Poutvaara (2005) have suggested that economic and cultural forces play an important role in shaping the international students migration markets. In addition to the teaching reputation, for many institutions in the UK, lecture and learning facilities, where provided to a high standard are perceived as having an important influence on students' choice of institution more than their research profiles (Price, Matzdorf, Smith, \& Agahi, 2003). Foskett, Maringe and Roberts (2006) found that students consider more carefully economic factors in times of distress and financial difficulty. These factors include job opportunities to supplement their incomes, accommodation costs and family home proximity. Also, course of study decisions tend to be closely related to institutional choice decisions. In their study to examine the factors affecting choice of college, Niu and Tienda (2008) added that geography also imposes constraints on college choices, that most students attend public, in-state institutions implies that college options are circumscribed by state of residence.

Simões and Soares (2010) studied students' decision-making process for higher education institutions, focusing on the pre-purchase period, and, in particular, the information sources and choice factors students draw on when selecting a higher education institution or a Portuguese university. Their study found that the university website is rated among the three most used sources of information by the majority of respondents. The results also showed that geographical proximity was the most important choice factor for a higher education institution.

Thus, based on the extant literature, factors most commonly associated with comprehensive college choice model include student background characteristics, aspirations and curiosity, educational achievement, social environment, financial and cost of education, institutional climate and reputation, and other institutional characteristics such as school location and educational policies. These factors influencing college and master's programme choice may differ from one research context to another. So in order to develop practical strategies for management in particular HEIs, it is important for each empirical study to contextualize the critical factors underlying the students' choices. The findings of this study will be compared to those reviewed in the literature to contribute to our theoretical understanding of the critical groups of latent factors that underpin students' choices of HEIs.

\subsection{Conceptual framework}

The review of existing literature provides the starting point in developing a conceptual framework to understand the factors that are likely to influence students' choice of masters' programmes of study in HEIs in the research context. However, in order to develop context specific variables that reflect the choice of masters' programme in HEI in SSA in general and in College of Technology Education, University of Education, Winneba in particular, a preliminary focus group interview was conducted by the researchers to find out other context specific unique factors that might be important for consideration. Combining the findings from existing literature and the focus group interviews, sixteen factors were initially obtained. These factors are depicted in the conceptual framework for this study (Figure 1), which are quality of teaching, fees/cost of programme, location of school, school's student support, influence of family, influence of friends and colleagues, influence of lecturers and administrative staff of the institution, influence of students' superiors at their job or organization, quality of lecture and learning facilities of the school, attitude towards the institution as a whole, attachment to the institution, uniqueness of the programmes offered, reputation of the institution, failure to gain alternative admission elsewhere, curiosity to school in different environments, and personal intentions to pursue further studies in the institution.

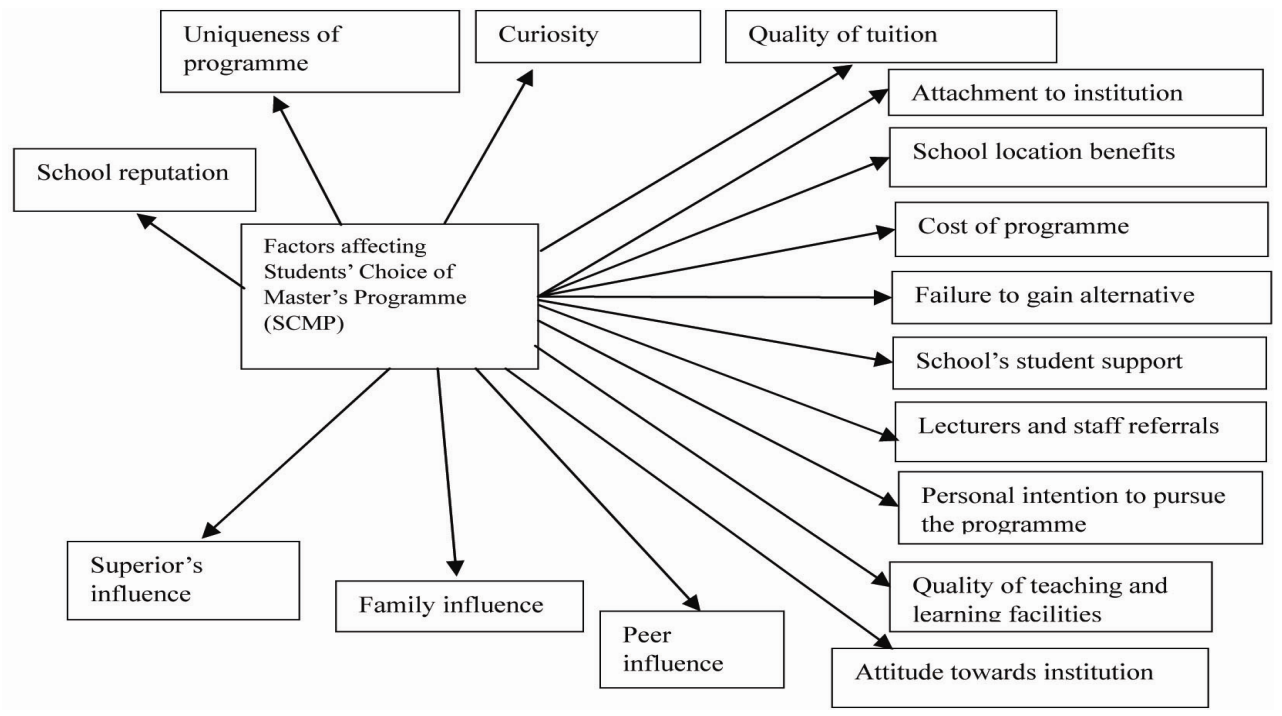

Figure 1. Conceptual Framework for the study 


\section{Methodology}

\subsection{Population and research context}

The population consisted of 597 second year students offering four types of master's degree programmes at the College of Technology Education, Kumasi Campus of the University of Education, Winneba (COLTEK). The University of Education, Winneba (UEW) is a Ghanaian public university established in 1992 and mandated to train professional teachers for all levels of education in the country. Currently, it has four main campuses located at Winneba, Kumasi, Asante-Mampong, and Ajumako respectively. The mission of the University is to train competent professional teachers for all levels of education as well as conduct research, disseminate knowledge and contribute to educational policies and development. The vision of the University is to be an internationally reputable institution for teacher education and research. Currently, COLTEK offers four different master's programmes, namely, Master in Business Administration (MBA), Master of Philosophy (MPHIL), Master of Arts (MA) in Educational Leadership and Master of Technology (MTECH).

\subsection{Sampling and Data Collection}

The second year group of master's students were the focus of this study because they were available for the survey. The first year master's students admitted were yet to start academic work, so access to them was very difficult. Out of the 597 second year master's students offering MBA, MPHIL, MA and MTECH programmes at COLTEK for the 2012/2013 academic year, 94 students offered MBA, 45 offered MPHIL, 230 offered MA and 228 offered MTECH programmes (UEW Basic Statistics, 2013). Based on the total population of 597 students, the appropriate sample size was statistically estimated using Yamane's (1967) formula that yielded a sample size of 240. Since the sample consisted of four sub-groups, an equal proportion of the total 240 was apportioned for each sub-group based on their respective percentage representation. This resulted in a sample 18 respondents for MPHIL group, 38 for MBA, 92 for MA and 92 for MTECH groups. In order to collect data of high quality that reflect the students' opinion, a survey was conducted in June 2013, which yielded a response rate of $76 \%$ from a usable 183 out of the 240 semi-structured questionnaire administered.

\subsection{Generation of research Instrument}

As already mentioned, a preliminary focus group interview was conducted by the researchers to find out factors that inform students choice of masters' programme for the study's purpose, using College of Technology Education, UEW as the research context. The outcome of the focus group interviews resulted in 41 items, which were used to develop the research instruments (see Table 1). A self-administered, structured questionnaire was then developed for the survey. The instrument was pre-tested to a sample of twenty (10) students for refinement in order to get a more effective instrument. It was finally administered to the target population through personal contact by researchers for nearly two weeks. The responses to the questionnaire items were a five-point Likert scale ranging from strongly disagree to strongly agree, coded 1 to 5 respectively. The questionnaire contained a section for demographic variables (gender, age, income, programme of study, previous school attended, and residence). It also had a section for items of evaluation for the factors that determined their choice of master's programme they are offering. For the initial validity and reliability of the instrument, the face and content validity were verified and established by two experts in research methodology. The item and construct reliability for all the 41 initial items were ascertained using the Cronbach alpha generated from the output of SPSS 16.0 (see Table 1). It produced a composite value of 0.832, which is above the recommended minimum of 0.7 (Hair, Black, Babin, \& Anderson, 2010).

\subsection{Data analysis method}

\subsubsection{Factor Analysis}

Factor Analysis (FA) is a data reduction technique that uses correlations between data variables. It assumes that some underlying factors exist that explains the correlations or inter-relationships among observed variables (Chatfield \& Collins, 1992). It has been used extensively in psychology, econometrics, marketing, sociology, and education (Bollen, 1989; Doll, Xia, \& Torkzadeh, 1994). Statistical data analysis for this study for FA followed the approach similar to the one used by Kettinger and Lee (1997) and Nimako, Azumah, Donkor and Adu-Brobbey (2012). Basically the steps involved are:

1. Exploratory factor analysis

2. Regrouping of items

3. Confirmatory factor analysis

4. Testing the validity and reliability of the emerged dimensions. 


\subsubsection{Exploratory factor analysis (EFA)}

EFA is a method that aims at extracting maximum variance from the dataset within each factor (Chatfield \& Collins, 1992). Costello and Osborne (2005) strongly recommended the use of Principal Component Analysis since it has the ability to reveal the underlying structure of the latent variables with an appropriate rotation method. On rotation methods the Varimax rotation methods is widely used, though Maximum Likelihood or Principal Axis Factoring are recommended where the dataset involved are generally normally-distributed or significantly non-normal, respectively (Costello \& Osborne, p. 2). Based on the literature, the present study adopted the Principal Component Analysis with Varimax rotation methods of EFA. This was performed on all 41 items of student master's progamme choice (SMPC) factors. The EFA involved initial tests of individual item reliability using the item communalities with acceptable value of 0.5 and Kaiser-Meyer-Olkin Measure to ascertain the suitability of the data for structure detection (Kline, 2005). For simplicity of analytical purpose each statement of the questionnaire was coded as QT1, QT2, FEE1, FEE2 and the like (see Table 1).

On the criteria for selecting factor loading, generally factor loading above 0.6 is considered high while factor loading greater than or equal to 0.3 is considered moderately high (Kline, 2005). Therefore the cut-off for analysing factor loading was 0.50 . Next, no items (rows) should have multiple factor loadings greater or equal to 0.50 . Lastly, no factors (columns) should have only one high loading item. Other factor loadings that do not satisfy the above criteria are considered meaningless and can be safely removed, while the high loading factors are critical factors and therefore can be retained. After the EFA, the next step in the data analysis is to perform a CFA on the remaining SMPC items using Principal Component Analysis with Variamax rotation to confirm the dimensionality of the derived instrument.

\section{Results}

\subsection{Respondents' characteristics}

For the characteristics of the respondents, in terms of gender, $70.4 \%$ of the respondents were males and $29.6 \%$ were females. $0.5 \%$ were below 25 years, $42.5 \%$ of the respondents were within the ages of $25-35$ years, $42.5 \%$ were between 36 and 45 years, and $13.4 \%$ were between $45-55$ years and $1.1 \%$ were 56 years and above. This implies that majority of them were in the economically active population. In terms of programme of study, $25.3 \%$ were offering MBA, $18.3 \%$ were offering MPHIL programmes, $55.4 \%$ were MA students and $1.1 \%$ were MTECH students. In terms of institutions where respondents obtained their first degrees, $61.8 \%$ had first degrees from University of Education, Winneba, 3.8\% from Kwame Nkrumah University of Science and Technology - Kumasi, 9.7\% from University of Ghana - Accra, 13.4\% from University of Cape Coast and $11.3 \%$ were from other higher institutions of learning in Ghana and West Africa. In terms of marital status, $72.0 \%$ of them were married, $25.5 \%$ were single (not married) while $2.5 \%$ of them were in other marital categories. In terms of monthly income, $3.8 \%$ of them earned below US\$250, 64\% of them earned between US\$ 250 and US\$ 500, 26.3\% earned between US\$ 501 and US\$ 750 and the rest $5.9 \%$ earned above US\$750. Finally, $46.2 \%$ of the respondents were residents in Kumasi city where COLTEK of UEW is located. $20 \%$ of them resided outside Kumasi in Ashanti Region of Ghana, which has Kumasi as its capital city, and $33.3 \%$ of the respondents resided in other regions of Ghana. Generally it can be deduced that about $60 \%$ of these students were former students of UEW. Moreover, most of the respondents are married and adults people who reside mostly outside Kumasi and earn considerable low incomes.

\subsection{Exploratory factor analysis}

In this study factor analysis was conducted using SPSS 16.0 for Windows. The results of the EFA (see Table 2) show a high value of 0.761 for the Kaiser-Meyer-Olkin measure and indicate the suitability of the research data for structure detection, i.e. the proportion of variance in the items that might be caused by underlying factors. Thus, generally the data is useful for factor analysis. This is confirmed by the significance of the Bartlett's test of sphericity tests $\left(X^{2}: 3585.755\right.$, df: 820, Sig.: 0.000) indicating that the variables are not unrelated and therefore suitable for structure detection. However, the initial communalities extracted (Table 1) indicate that twenty-five (25) items (see items with strike-throughs) were not reliable since their values were below 0.50. In effect, out of the initial 41 items of SMPC that generated 11 factor components, 25 items of SMPC were eliminated because they did not satisfy the criteria set for factor loading selection; these are indicated with strike-through. Sixteen (16) items of SMPC were not affected at all, therefore, they were retained for further analysis. In all, seven factor components emerged. 
Table 1. EFA of Measurement item and Scale Reliability for SMPC

\begin{tabular}{|c|c|c|}
\hline Code & Item of SMPC & CE \\
\hline QT1 & Because of the quality of teaching they provide & $\theta .402$ \\
\hline QT2 & Because the lecturers are competent in their subject areas & 0.414 \\
\hline QT3 & Because of the quality of the profite of the teaching staff & $\theta .384$ \\
\hline FEE1 & Because the fee is comparatively affordable & 0.737 \\
\hline FEE2 & Because the cost of the programme is considerably affordable & 0.908 \\
\hline LOC1 & Because the school's location is close to me & 0.557 \\
\hline LOC2 & Because the school's location allows me to combine work and college conveniently. & 0.647 \\
\hline LOC3 & Because the college is located in Kumasi where I can easily attend classes & 0.610 \\
\hline SST1 & Because the college has quality student support systems & $\theta .491$ \\
\hline SST2 & Because the college has quality counseling sessions for students & $\theta .458$ \\
\hline SST3 & Because the college has students' needs at heart & 0.801 \\
\hline SST4 & Because the college is responsive to students' needs & 0.707 \\
\hline SNF1 & Because members of my family are associated with this college & $\theta .336$ \\
\hline SNF2 & Because my family encouraged me to be part of the master's programme & 0.362 \\
\hline SNP1 & Because my friends influenced me to do the programme in this college. & $\theta .473$ \\
\hline SNS1 & Because I was encouraged by some staff of COLTEK to do the master's programme & 0.643 \\
\hline SNS2 & $\begin{array}{l}\text { Because I was encouraged by some lecturers in COLTEK to come on the master's } \\
\text { programme }\end{array}$ & 0.861 \\
\hline EFC1 & Because the college has god lecture facilities & $\theta .285$ \\
\hline LFC2 & Because the college has good library facility & 0.449 \\
\hline LFC3 & Because the college has great resources for learning & $\theta .402$ \\
\hline ATT1 & Because I have positive attitude towards UEW & 0.540 \\
\hline ATA1 & Because I feel part of the UEW family & 0.810 \\
\hline ATT2 & Because I want to continue to be part of UEW family & 0.760 \\
\hline $\operatorname{ATA2}$ & Because I have developed strong interest for UEW programmes & $\theta .495$ \\
\hline ATA3 & Because I am very familiar with the UEW system of college & 0.443 \\
\hline UNQ1 & Because the master's programme I wanted was unique at COLTEK & $\theta .312$ \\
\hline UNQ2 & Because the master's programme is offered by this campus only in the region & $\theta .263$ \\
\hline REP1 & Because I believed UEW has reputation for quality academic standards & 0.495 \\
\hline REP2 & Because the university has good image & $\theta .446$ \\
\hline SNB1 & Because my superior(s) in my organization advised me to doso & $\theta .443$ \\
\hline SNP2 & Because my colleagues encouraged me to do so. & $\theta .158$ \\
\hline ALT1 & Because that was the only opportunity I had to further my education. & $\theta .207$ \\
\hline ALT2 & Because I was refused admission in another institution & 0.816 \\
\hline ALT3 & Because I did not get admission in my preferred institution & 0.685 \\
\hline ALT4 & Because my chance of getting admission elsewhere was very small. & $\theta .467$ \\
\hline EUR1 & Iusually like to try out new programmes of other universities /institutions. & $\theta .344$ \\
\hline CUR2 & $\begin{array}{l}\text { Thave strong interest to experience the teaching, learning and programme of study of } \\
\text { other universities/institutions. }\end{array}$ & 0.096 \\
\hline EUR3 & Generally, Ilike to study in new schoolenvirenments & $\theta .362$ \\
\hline INT1 & It was my intention to come to UEW for a master's programme. & 0.805 \\
\hline INT2 & I was determined to apply for admission to a master's programme in UEW & 0.674 \\
\hline \multirow[t]{6}{*}{ INT3 } & Generally, I thought of doing a master's programme at COLTEK & $\theta .496$ \\
\hline & Initial Reliability Statistics & \\
\hline & All 41 items - Cronbach alpha reliability & 0.832 \\
\hline & Kaiser-Meyer-Olkin Measure (KMO) & 0.761 \\
\hline & Bartlett's test of sphericity tests $\left(X^{2}: 3585.755\right.$, df: 820 , Sig.: 0.000$)$ & \\
\hline & Initial total variance explained & 56.358 \\
\hline
\end{tabular}

Note: CE - Communalities Extracted, Values with strike-through are below the acceptable communality of 0.5. 


\subsection{Grouping of items}

As shown in Table 2, seven components or factors were derived. Some of the derived dimensions were then relabelled. The labels were intuitively chosen based on the meaning suggested within the context of housing industry. These are consistent with labelling and coding textual data (Strauss \& Corbin, 1998; Wilkin \& Castleman, 2003) and the justifications for these labels are as follows:

Factor 1 is dominated by three emotional and attitudinal items related to association with the University. These items are positive attitude towards the University (ATT1), a feeling of being part of the University (ATA 1) and a desire to continue to be a part of the University (ATA 2). Out of these three items, two of them ATA1 and ATA2 are attachment factors and one of them, ATT1, relates to a positive attitude towards the University. Since this group is dominated by attachment or emotional items, the appropriate label for it was Attachment to the University.

Factor 2 contained three items derived from the original location dimension. These are proximity of school location to respondents' residence, convenience derived from school's location items allowing respondent to combine work and college conveniently, perceived easiness of schools' locations in the central business district of Kumasi, where respondent can easily attend classes. None of the original location items was eliminated, therefore, it was retained as Institutions location benefits dimension.

Factor 3 had only two items from the original Fee or Cost dimension. These are affordability of the tuition fee compared with that of other competitor institutions (FEE1) and the affordability in terms of the overall cost of the masters' programme of study (FEE2). These two cost items basically relate to affordability of fees for the respondents' preferred programme of study as compared to what other competitor institutions are charging for the same or similar programme of study. It also includes other cost associated with the programme of study such as charges for practical work and scientific experiment, cost of books and study materials, feeding, accommodation, among others. Since this factor contains the two items of tuition fees and other cost of the master's programme, this dimension was retained or labelled as Cost of Programme.

Factor 4 contained the two items of availability of alternative admission. These are, being refused admission in another institution (ALT2) and inability to gain admission in respondents' most preferred institution (ALT3). Since these two items basically relate to inability to get admission from a competitive and most preferred institution, it is labelled as failure to gain alternative admissions.

Factor 5 contained the two items of student support dimension. These are the college having students' needs at heart (SST3) and college being perceived by respondents as responsive to students' needs (SST4). These two student support items fundamentally relate to how the college is able to provide institutional and human resource support to help students solve their problems timely, conveniently and effectively. Since the two items come from the original student support dimension, its label was retained.

Factor 6 consisted of the two items that described the influence of other people in respondents' decision to choose a master's programme in the University. These items are encouragement by staff of the University (SSN1) and influence of lecturers in the University (SSN2). These two basically highlight the role of the University's academic and non-academic staff in attracting and retaining previous students of the University as well as potential ones. The factor depicts the influence of university members, therefore, it was labelled lecturers and staff recommendations. 
Table 2. Results of exploratory factor analysis

\begin{tabular}{|c|c|c|c|c|c|c|c|}
\hline & \multicolumn{7}{|c|}{ Component/Factor } \\
\hline & 1 & 2 & 3 & 4 & 5 & 6 & 7 \\
\hline $\begin{array}{l}\text { Because the fee is comparatively affordable - } \\
\text { FEE1 }\end{array}$ & -0.041 & 0.047 & 0.079 & -0.128 & 0.916 & 0.105 & -0.122 \\
\hline $\begin{array}{l}\text { Because the cost of the programme is } \\
\text { considerably affordable - FEE } 2\end{array}$ & -0.042 & 0.044 & 0.168 & -0.106 & 0.913 & 0.014 & -0.113 \\
\hline Because the school's location is close to me & 0.095 & 0.00 & 0.797 & 0.063 & 0.164 & -0.113 & 0.046 \\
\hline $\begin{array}{l}\text { Because the school's location allows me to } \\
\text { combine work and college conveniently. }\end{array}$ & 0.071 & 0.009 & 0.823 & 0.085 & 0.144 & 0.002 & 0.027 \\
\hline $\begin{array}{l}\text { Because the college is located in Kumasi } \\
\text { where I can easily attend classes }\end{array}$ & 0.02 & -0.049 & 0.832 & -0.076 & -0.065 & -0.065 & 0.024 \\
\hline $\begin{array}{l}\text { Because the college has students' needs at } \\
\text { heart }\end{array}$ & 0.283 & 0.039 & 0.006 & 0.874 & -0.142 & -0.059 & 0.3 \\
\hline $\begin{array}{l}\text { Because the college is responsive to students' } \\
\text { needs }\end{array}$ & 0.345 & 0.089 & -0.002 & 0.838 & -0.146 & -0.078 & 0.287 \\
\hline $\begin{array}{l}\text { Because I was encouraged by some staff of } \\
\text { COLTEK to do the master's programme }\end{array}$ & 0.158 & 0.839 & -0.08 & -0.009 & 0.075 & 0.209 & 0.093 \\
\hline $\begin{array}{l}\text { Because I was encouraged by some lecturers } \\
\text { in COLTEK to come on the master's }\end{array}$ & & & & & & & \\
\hline $\begin{array}{l}\text { programme } \\
\text { Because I have positive attitude towards }\end{array}$ & 0.173 & 0.828 & -0.167 & 0.152 & 0.117 & 0.227 & 0.141 \\
\hline UEW & 0.735 & 0.127 & 0.174 & 0.213 & 0.011 & -0.143 & 0.289 \\
\hline Because I feel part of the UEW family & 0.897 & 0.157 & 0.015 & 0.177 & 0.022 & 0.009 & 0.358 \\
\hline $\begin{array}{l}\text { Because I want to continue to be part of UEW } \\
\text { family }\end{array}$ & 0.889 & 0.119 & 0.089 & 0.19 & 0.021 & -0.062 & 0.276 \\
\hline $\begin{array}{l}\text { Because I was refused admission in another } \\
\text { institution }\end{array}$ & -0.051 & 0.057 & 0.033 & -0.086 & 0.026 & 0.824 & -0.102 \\
\hline $\begin{array}{l}\text { Because I did not get admission in my } \\
\text { preferred institution }\end{array}$ & -0.081 & 0.17 & 0.049 & -0.012 & 0.022 & 0.905 & -0.031 \\
\hline $\begin{array}{l}\text { It was my intention to come to UEW for a } \\
\text { master's programme. }\end{array}$ & 0.322 & 0.062 & 0.042 & 0.215 & 0.124 & -0.119 & 0.849 \\
\hline $\begin{array}{l}\text { I was determined to apply for admission to a } \\
\text { master's programme in UEW }\end{array}$ & 0.397 & 0.116 & 0.049 & 0.246 & -0.133 & -0.094 & 0.88 \\
\hline
\end{tabular}

Notes: Extraction Method: Principal Component Analysis. Rotation Method: Oblimin with Kaiser Normalization

Factor 7 consisted of the two items of intentions of respondents to offer a master's programme in the University. These intentions items describe respondents' rational decision making process by which they carefully consider to pursue a master's programme in the University (INT1) and respondents' own pre-conceived determination to apply to offer a master's programme in the university (INT2). Obviously, the two intention items are from the original dimension called personal intentions to pursue master's programme, therefore, its label was retained.

4.4 Confirmatory factor analysis (CFA) on the remaining 16 items

Confirmatory Factor Analysis (CFA) on the remaining 16 items was done using principal component analysis (PCA) extraction method with Varimax rotation to confirm the dimensionality of the derived instrument (Table 3). The CFA was run based on the procedure explained above. The total variance explained is 72.261 , which means the underlying components derived explain about $72.26 \%$ of the underlying factors that determine students' choice of masters' programme in the research context. With factor loadings above 0.60 , all the 16 confirmed items could be considered strong (Kline, 2005). Thus, the results of the CFA in Table 3 provide strong evidence to confirm the derived dimensions of the EFA in Table 2. 
Table 3. Confirmatory factor analysis of remaining 16 SMPC items

\begin{tabular}{|c|c|c|c|c|c|c|c|}
\hline & \multicolumn{7}{|c|}{ Rotated Component Matrix ${ }^{a}$} \\
\hline \multicolumn{8}{|c|}{ Component } \\
\hline & 1 & 2 & 3 & 4 & 5 & 6 & 7 \\
\hline INT1 & .373 & .061 & -.125 & -.098 & .303 & -.091 & .897 \\
\hline INT2 & .402 & .046 & -.118 & -.081 & .312 & -.109 & .819 \\
\hline SNS1 & .157 & -.075 & .074 & .208 & .024 & -.798 & .083 \\
\hline SNS2 & .169 & -.146 & .093 & .173 & .142 & -.925 & .121 \\
\hline SST3 & .312 & .001 & -.137 & -.057 & .893 & -.047 & .329 \\
\hline SST4 & .326 & .020 & -.155 & -.127 & .837 & -.110 & .307 \\
\hline ALT2 & -.024 & -.073 & .049 & .899 & -.112 & -.138 & -.122 \\
\hline ALT3 & -.089 & -.068 & .024 & .821 & -.063 & -.251 & -.057 \\
\hline FEE1 & -.018 & .121 & .857 & .061 & -.153 & -.094 & -.153 \\
\hline FEE2 & -.002 & .193 & .952 & .018 & -.151 & -.072 & -.117 \\
\hline LOC1 & .124 & .739 & .198 & -.095 & .049 & .061 & .094 \\
\hline LOC2 & .075 & .796 & .189 & -.030 & .077 & .080 & .025 \\
\hline LOC3 & .039 & .763 & .019 & -.066 & -.090 & .150 & .034 \\
\hline ATT1 & .718 & .135 & .038 & -.073 & .321 & -.116 & .425 \\
\hline ATA1 & .896 & .039 & -.029 & -.016 & .301 & -.213 & .413 \\
\hline ATT2 & .869 & .087 & -.003 & -.075 & .298 & -.145 & .322 \\
\hline
\end{tabular}

Extraction Method: Principal Component Analysis. Rotation Method: Oblimin with Kaiser Normalization.

\subsection{Validity and reliability of derived instrument}

In factor analysis, the reliability and validity of the derived instrument must be assessed in order to confirm the labelled or emerged dimensions or constructs (Hair et al., 2010; Straub, Boudreau, \& Gefen, 2004). Instrument validity refers to whether the statistical instrument measures what it is intended to measure (Straub et al., 2004). Construct validity refers to whether an instrument is able to measure what it is supposed to measure to an overall theoretical framework in order to determine whether the device confirms a series of hypothesis derived from an existing theoretical framework. In this work, the questionnaire items for this study were based on literature reviews and experts' review to ensure its content and construct validity. The survey instrument items were grounded in theoretical framework for student choice of colleges and programmes of study (e.g., bin Khairani \& Razak, 2013; Hossler et al., 1999; Vrontis, et al., 2007). The two main aspects of construct validity, being, convergent validity and discriminant validity, can be deduced from the CFA results (Straub et al., 2004). Since the items converge strongly to the derived dimensions, good convergent validity is indicated in the "strong" factor loadings. Also discriminant validity can be deduced because the factor loadings indicate that the items do not overlap across different dimensions.

Reliability refers to whether a measurement instrument is able to yield consistent results each time it is applied (Hair et al., 2010; Straub et al., 2004). Statistically, several useful methods are available in assessing the reliability of constructs in CFA. These measures are the summated scale (average of the factor loadings) for a component, Cronbach alpha with acceptable value of 0.7 and above (Straub et al., 2004), composite reliability with acceptable value of 0.7, and Average Variance Extracted (AVE) with acceptable value of 0.5 and above (Hair et al., 2010). The reliability results for composite reliability (CR) and AVE are presented in Table 4 for each derived dimension of SMPC. Taken together, the CR values are above 0.80 , the AVEs are above 0.5 and Cronbach alpha for each factor is above 0.70 , thus indicating good reliability. Overall, the AVE is $76.2 \%$ indicating the items explain well the factors or dimensions they represent. 
Table 4. Labelling and Reliability of Derived Dimensions

\begin{tabular}{|c|c|c|c|c|c|c|c|}
\hline Factors & Labels & $\begin{array}{l}\text { No. } \\
\text { Items }\end{array}$ & AVE & $\mathbf{C R}$ & CA & SMS & $\begin{array}{l}\text { Ranking } \\
\text { of SMS }\end{array}$ \\
\hline 1 & Attachment to University & 3 & 0.784 & 0.916 & 0.863 & 0.828 & 6 th \\
\hline 2 & School location benefits & 3 & 0.680 & 0.863 & 0.804 & 0.766 & 7 th \\
\hline 3 & Cost of programme & 2 & 0.907 & 0.951 & 0.898 & 0.905 & $1 \mathrm{st}$ \\
\hline 4 & Failure to gain alternative admissions & 2 & 0.847 & 0.917 & 0.843 & 0.860 & 4 th \\
\hline 5 & Student support & 2 & 0.872 & 0.932 & 0.853 & 0.865 & 2 nd \\
\hline 6 & Lecturers and staff recommendations & 2 & 0.864 & 0.927 & 0.847 & 0.862 & $3 \mathrm{rd}$ \\
\hline \multirow[t]{2}{*}{7} & Personal intention to pursue master's programme & 2 & 0.867 & 0.929 & 0.847 & 0.858 & 5 th \\
\hline & Variance extracted for all items & 16 & 0.762 & & & & \\
\hline
\end{tabular}

Notes: AVE - Average variance extracted, CR - composite reliability, CA - Cronbach alpha, SMS - Summated scale

\subsection{Ranking of derived factors of SCMP}

In order to describe the relative importance of the derived latent factors of SCMP, a ranking of the summated scale (SMS) was conducted (DiStefano, Zhu \& Mîndrilă, 2009). Summated scale is the average of the items' loading within each derived component of factors after the final confirmatory factor analysis (DiStefano, Zhu \& Mîndrilă, 2009; Hair et al., 2010). The ranking of the summated scale for each factor or component is presented in Table 4. It shows that cost of programme is ranked first as the most important factor that influenced the respondents' choice of their master's programmes, followed by school's student support, third is recommendations from lecturers and staff, fourth is failure to gain alternative admissions, fifth is students' personal intentions to pursue the programmes, sixth is students' attachment to the university, and the least is school's location benefits.

\section{Discussion and Implications}

The main focus of this paper was to examine the underlining factors in students' choice of HEIs masters' programme in a public university in a SSA context. The results of the study show that seven principal factors emerged which indicate the key underlying factors of students' choice of masters' progammes. The seven emerged dimensions have sixteen items in all, which are presented in Figure 2 and Table 5.The meaning and implications of derived dimensions and their corresponding measurement items are discussed as follows.

\section{Cost of the programme}

This factor was the first in priority. It essentially relates to affordability of the fees for the respondents preferred programme of study in terms of tuition fees as compared to what other competitor institutions are charging for the same or similar programme of study. It also includes other cost associated with the programme of study such as charges for practical work and scientific experiment, cost of books and study materials, feeding, accommodation, among others. The top priority this dimension occupies implies that in COLTEK, most students enroll on master's programmes principally because the cost of the programmes is relatively less expensive compared with other competing HEIs in Ghana.

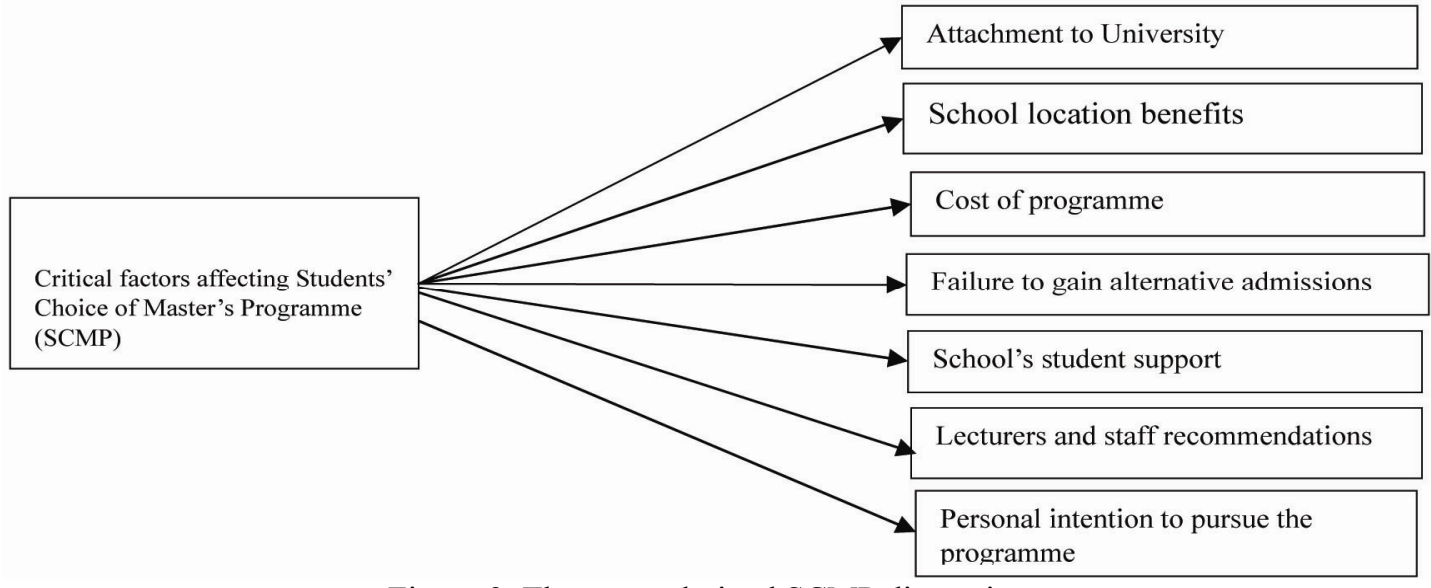

Figure 2. The seven derived SCMP dimensions 
Table 5. Derived SCMP Scale

\begin{tabular}{|c|c|c|}
\hline Code & Dimension & Indicators \\
\hline FEE1 & Coct of prooromm & Because the fee is comparatively affordable \\
\hline FEE2 & cost of programme & Because the cost of the programme is considerably affordable \\
\hline LOC1 & & Because the school's location is close to me \\
\hline LOC2 & School location benefits & Because the school's location allows me to combine work and study... \\
\hline LOC3 & & Because the college is located in Kumasi where I can easily attend classes \\
\hline SST3 & Schools' student support & Because the college has students' needs at heart \\
\hline SST4 & & Because the college is responsive to students' needs \\
\hline SN1 & & Because I was encouraged by some staff of COLTEK to do the master's \\
\hline SN2 & $\begin{array}{l}\text { Lecturers and staff } \\
\text { recommendations }\end{array}$ & $\begin{array}{l}\text { programme } \\
\text { Because I was encouraged by some lecturers in COLTEK to come on the } \\
\text { master's programme }\end{array}$ \\
\hline ATT1 & & Because I have positive attitude towards UEW \\
\hline ATA1 & Attachment to university & Because I feel part of the UEW family \\
\hline ATT2 & & Because I want to continue to be part of UEW family \\
\hline ALT2 & Failure to gain alternative & Because I was refused admission in another institution \\
\hline ALT3 & admission & Because I did not get admission in my preferred institution \\
\hline INT2 & Personal intentions to pursue & It was my intention to come to UEW for a master's programme. \\
\hline INT3 & the master programme & I was determined to apply for admission to a master's programme in UEW \\
\hline
\end{tabular}

This finding lends support to many previous studies that financial cost continues to be an important factor in students' choice of institution for master's programmes (e.g., Sidin, Hussin, \& Soon, 2003; Paulsen \& St John, 2002; Wilkins, Shams, \& Huisman, 2013). Consistent with this study's finding, Sidin, Hussin and Soon (2003) found that in Malaysia income affects the choice of students along the public-private education divide. In developing country SSA where income levels are generally low, economic considerations in terms of students' ability to obtain adequate finance to pay for cost of programmes in HEIs continues to be a teething issue. Therefore, students' choice of HEIs and master's programmes is greatly influenced by cost-benefit consideration.

In view of this, the findings of this study suggest that students' choice of master's programmes in SSA context appears to be dominated by economic models of students' choice of HEIs. The findings on cost of programme factor imply that management of HEIs in SSA need to develop affordable programmes in order to attract students and remain competitive. Moreover, management could also begin to rethink of strategies to financially assist local and foreign students to be able to finance their education in HEIs especially for students with low socio-economic status in SSA countries (Terenzini et al., 2001). In this regard, all available sources of students' educational funds should be explored including scholarship schemes, partnership with donor agencies and institution-based student loan to be repaid by students in the form of rendering some services to the institution during or after school, among others.

Student support quality: This dimension was the second rated by the respondents in order of importance. It represents the institution's ability to provide institutional and human resource support to help students solve their problems timely, conveniently and effectively. Student support is recognised as an indispensable aspect of effective management of educational institutions both online and offline modes of education (Anderson \& Simpson, 2014; Rumble, 2000; Potter, 2013), which is taken into consideration in students' search and information processing in their choice of college and programme of study in HEIs (Hossler et al., 1999). It supplements the academic process and provides an enabling school environment for effective educational management as well as faculty and students' overall development. Support for students can take several forms including administrative, communication, academic, financial, medical, counselling, sports and entertainment, housing and accommodation and providing for the physically challenge (Anderson \& Simpson, 2014; bin Khairani \& Razak, 2013). These aspects of student support quality combine to give an overall expression of the quality of responsiveness of school administration, which in turn communicates to stakeholders a sense of having students' needs at heart and readiness to be responsive to students' needs. Therefore, student support quality becomes a very important factor in college and programme of study selection factor for prospective students, not only in advanced countries (e.g., Rumble, 2000; Potter, 2013) but also in developing countries as well (Sidin et al., 2003).

Theoretically this finding supports some existing work (e.g., Sidin et al., 2003) conducted in developed countries. It implies that management need to pay close attention to this factor as it serves as an important source of competitive advantage to the institution in question for attracting potential master's students within the competition of HEIs in 
Ghana. Management needs to develop effective monitoring systems for ensuring adequate provision of student support facilities to meet the changing needs of students in the 21 st century.

Recommendation from lecturers and staff: This factor was rated third in importance. It reflects the combined influence of faculty and other staff in attracting potential students to pursue different master's programme of study. New and potential students rely on the positive advice and recommendations from peers, parents, friends, existing staff and faculty in HEIs to concretise their selection of particular college and programmes of study (Ceja, 2006). It is a fact that word-of-mouth communication from members of HEIs are held in high esteem by outsiders (Allsop, Bassett, \& Hoskins, 2007) and are perceived to be more credible than other sources. Though recommendation from social and referent groups (e.g., member of HEIs) may have its own demerits, it continues to be a strong factor that influences most prospective students' choices in college and programme of study selection (Ceja, 2006) as it is in this study.

Theoretically, this factor reflects the multi-faceted nature of students' sources of information during their search for most suitable colleges and programmes of study. It emphasises the role of significant others as opined in The Chapman model, the information search stage of The Hanson and Litten model and the Information-Processing Models for explaining students' college and programme of study choice process. The influence of social and referent groups in decision making process has long been recognised in the psychology and human behaviour literature as an important determinant of intentions and actual behaviour (Ajzen, 1991).

The implications of this factor to management in HEIs in developing countries is that there is the need to improve staff and faculty perception of the HEIs within which they work. This calls for effective human resource management strategies that focus on developing organisational citizenship and commitment among people in the organisation. As more and better human resource efforts are put in place to treat people well and make them feel part of the institution, it can yield far reaching future benefits for the organisation. It has the potential of inducing positive recommendations from employees for their employers in HEIs in developing countries.

Staff recommendations to customers and potential business partners form part of the expectations of the employers from their employees in the psychological contract in employment relations (Patrick, 2008). Previous studies have found that referrals from staff could be an important source of advertisement for organisations (Mishra \& Sinha, 2014). As a source of advertisement for HEIs, staff and students' recommendations could be less expensive to the organisation, more frequent and influential than advertising through the mass media. Consequently, management of HEIs need to develop effective reward systems for staff and students' recommendations as a source of motivation towards inducing frequent and purposeful recommendations of faculty, other staff and students to win more potential students to the institutions. In Ghana, for example, the Accra Institute of Technology rewards existing students who identify and attract other potential students by giving them a special concession in their fees; each new student brought to the school by another student attracts a commission.

Failure to gain alternative admissions: This was the fourth ranked factor. It has to do with the fact that prospective students who do not gain admission elsewhere as a first priority tend to seek for alternative admission. One probable reason for this situation is that, as the education industry becomes more and more competitive, it demands varied admission criteria across similar colleges and programmes of study. Consequently, prospective applicants also tend to apply for admission in more than one college and make judgment about which programme of study to consider as first, second and third choices. These are all precautionary efforts to secure admission during a given academic year and not defer it to a later time. The implication this finding to management is that HEIs that are relatively newly established need to develop strategies to absorb prospective students, especially those who qualify but fail to gain admission in some preferred schools. Late admission, extension of admission dates, and fee paying options are among the many marketing strategies that could be adopted to attract such qualified but unfortunate prospective students.

Personal intention to pursue master's programme: This factor was ranked fifth in priority. It describes respondents' rational decision making process by which they carefully consider to pursue a master's programme in the HEI. It reflects their personal pre-conceived determination to apply to do the master's programme of their choice in the HEI. Intentions to act captures the all relevant motivational factors that drive individuals to determine to act or implement a decision (Ajeiz, 1991). Although not all behaviours are preceded by conscious and rational thinking, most behaviours such as choosing a HEI to pursue a desired master's programme require a thoughtful process and personal intention to act. This finding confirms many rational human behaviour theories such as the Theory of Planned Behaviour (Ajzen, 1991), which suggests that intentions are important underlying factors in many human choices and behaviour. The implication to management is to be able to trace and detect some of the factors that 
predict prospective students' intentions to choose a particular HEI and/or a master's programme. Most of the critical factors identified in this study are likely to contribute significantly to influencing the respondents' underlying intentions. Thus, further research would be done using this dataset in this direction.

Attachment to university: This factor was ranked sixth in priority. It captures prospective students' attitudinal and emotional variables that influence their choice of HEIs and masters' programmes. For this study, the results indicated that prospective students developed positive attitude and feeling of being part of the institution. Most of them who were previous students at the undergraduate level indicated a desire to continue to be a part of the institution. This confirms existing literature that emphasizes the important role an individual's attitudinal and emotional beliefs in influencing students' choices (Johnson, Crosnoe, \& Elder Jr, 2001; Robbins, Lauver, Le, Davis, Langley, \& Carlstrom, 2004). Robbins et al. (2004) found that attitudinal beliefs of prospective students played significant role in their college choice. Individual positive attitudes and attachment to institutions are built from their experiences and image of the institution. Therefore, the implication to management is that there is the need to continue to create strong emotional, structural and relationship bonds between the organisation and its existing members in order to induce their commitment and attachment to the institution.

School location benefits: This factor received the seventh ranking in priority. Although location benefits appear to be the least mentioned factor, it is still critical and significant. Location benefits still determines some prospective students' choice of college and programmes of study. This factor includes all the benefits a prospective student hopes to derive from the geographical location of the HEI in question such as proximity of HEI to applicant's cultural decent, family, a favourite sports club, future place of residence, or some prestige or favourable historical records associated with the location of the HEI, availability of jobs or good economic and climatic conditions, among others. In the literature, there is evidence that geographical factors play a key role in the choices of some college students (e.g., Foskett et al., 2006; Niu \& Tienda, 2008). According to Niu and Tienda (2008), geography also imposes constraints on college choices, that most students attend public, in-state institutions implies that college options are circumscribed by state of residence. The implication of this finding to management is that the attractiveness of school's location can be a strong competitive advantage for attracting qualified applicants.

Using the derived scale: The derived dimensions constitute critical factors underlying students' choice of college for masters' programme from a developing country perspective. Therefore, the derived measurement items and factors could serve as an important starting point to be considered by researchers that want to conduct research in a similar area in developing country contexts.

\section{Limitations and further research}

The main limitation of this study is that it used samples from one public HEI in a developing country. It is cautioned that the results of the present study should be interpreted within the context of Sub-Saharan Africa, especially Ghanaian HEIs. Similar studies should be done in similar contexts to compare the results before generalisations could be made. Finally, future research should explore other critical factors not discovered in this study by extending the study to other HEIs in different developed and emerging countries for a better understanding of students' college process and how it can be managed effectively by HEIs.

A further study should be conducted to explore how the six of the emerged critical factors predict students' intentions or pre-conceived determination to pursue the programme at COLTEK, using structural equation approach or similar methodology. This will enhance management and scholars' understanding of which factor contributes significantly or the most to students' intentions in choosing the institution for their preferred master's programme.

\section{Conclusion}

Empirical research on students' college choice factors in developing countries is limited. This study provides an empirical framework for understanding some of the critical factors underlying college students' choice of masters' programme in HEIs from a developing country perspective. Using sample of second year master's students in a public university in Ghana, the results of the factors analysis indicate that seven main factors emerged. These are: cost of the programme, student support quality, recommendation from lecturers and staff, failure to gain alternative admissions, personal intention to pursue master's programme, attachment to university and school location benefits. These factors are critical and therefore management of HEIs in developing countries in SSA should focus on developing strategies to management them as they could be sources of competitive advantage. Management of higher education are also encouraged to use the derived measurement items and factors as an important starting point to be considered by researchers that wants to conduct research in a similar area/topic in developing country contexts. 
This paper adds to the limited empirical research in understanding student selection factors as far as accessing academic programmes in higher education in developing countries is concerned.

\section{References}

Ajzen, I. (1991). The theory of planned behavior. Organizational Behavior and Human Decision Processes, 50, 179-211. http://dx.doi.org/10.1016/0749-5978(91)90020-T

Allsop, D. T., Bassett, B. R., \& Hoskins, J. A. (2007). Word-of-mouth research: principles and applications. Journal of Advertising Research, 47(4), 398-411. http://dx.doi.org/10.2501/S0021849907070419

Anderson, B., \& Simpson, M. (2014). Group and Class Contexts for Learning and Support Online: Learning and affective support online in small group and class contexts.

Beggs, J. M., Bantham, J. H., \& Taylor, S. (2008). Distinguishing the Factors Influencing College Students' Choice of Major. College Student Journal, 42(2), 381-394.

bin Khairani, A. Z., \& Razak, N. B. A. (2013). Assessing Factors Influencing Students' Choice of Malaysian Public University: A Rasch Model Analysis. International Journal of Applied Psychology,3(1), 19-24. doi:10.5923/j.ijap.20130301.04

Briggs, S., \& Wilson, A. (2007). Which university? A study of the influence of cost and information factors on Scottish undergraduate choice. Journal of Higher Education Policy and Management,29(1), 57-72. http://dx.doi.org/10.1080/13600800601175789

Ceja, M. (2006). Understanding the role of parents and siblings as information sources in the college choice process of Chicana students. Journal of College Student Development, 47(1), 87-104. http://dx.doi.org/10.1353/csd.2006.0003

Chatfield, C., \& Collins, A. J. (1992). Introduction to Mult-variate Analysis, Chapman and Hall, London.

Chapman, D. (1981). A model of student college choice. Journal of Higher Education, 52(5), 490-505.

DiStefano, Christine, Zhu, Min \& Mîndrilă, Diana (2009). Understanding and Using Factor Scores: Considerations for the Applied Researcher. Practical Assessment, Research \& Evaluation, 14 (20). Available online: $\mathrm{http}: / /$ pareonline.net/getvn.asp? $\mathrm{v}=14 \& \mathrm{n}=20$

Dreher, A., \& Poutvaara, P. (2005). Student flows and migration: An empirical analysis. CESifo working papers, No.1490, 1-24.

Ellwood, D., \& Kane, T. J. (2000). Who is getting a college education? Family background and the growing gaps in enrollment. Securing the future: Investing in children from birth to college, 283-324.

Foskett, F., Rosalind. (2006): Postgraduate study in the UK: the international student's guide, London, UK, Sage, 211.

Foskett, N., F. Maringe \& D. Roberts. 2006. Changing fee regimes and their impact on student attitude to higher education. Higher Education Academy UK 22(2): 23-31.

Hair, J. F., Black, W. C., Babin, B. J., \& Anderson, R. E. (2010). Multivariate Data Analysis, Englewood Cliffs, NJ: Prentice Hall.

Hanson, K., \& Litten, L. (1982). Mapping the road to academia: A review of research on women, men, and the college selection process. N P. Perun (Ed.), The undergraduate woman, Issues in education. Lexington, MA: Lexington.

Hossler, D., Braxton, J., \& Coopersmith, G. (1989). Understanding student college choice. In J. C. Smart (Ed.), Higher education: Handbook of theory and research. Vol. V (pp. 231-288). New York, NY: Agathon Press.

Hossler, D., Schmit, J., \& Vesper, N. (1999). Going to college: How social, economic, and educational factors influence the decisions students make. Baltimore, MD: The Johns Hopkins University Press

Jackson, G. A. (1982). Public efficiency and private choice in higher education. Educational Evaluation and Policy Analysis 4(2): 237-247. http://dx.doi.org/10.3102/01623737004002237

Johnson, M. K., Crosnoe, R., \& Elder Jr, G. H. (2001). Students' attachment and academic engagement: The role of race and ethnicity. Sociology of Education, 318-340. http://dx.doi.org/10.2307/2673138

Kallio, R. E. (1995). Factors influencing the college choice decisions of graduate students. Research in Higher Education, 36(1), 109-124. http://dx.doi.org/10.1007/BF02207769 
Lalande, V. (1995). Student support via audio teleconferencing: Psycho-educational workshops for post bachelor nursing students. American Journal of Distance Education, 9(3) 62-73. http://dx.doi.org/10.1080/08923649509526898

Liu, J. (2005). Factors influencing students' choice of selected private universities in China. PhD Thesis. Bringham Young University, Proquest, UMI Number: 3189180.

Ming, J. S. K. (2010). Institutional factors influencing students' college choice decision in Malaysia: A conceptual framework. International Journal of Business and Social Science, 1(3), 53-58.

Mishra, T., \& Sinha, S. (2014). Employee motivation as a tool to implement internal marketing. organization, 3(5). 672-679.

National Accredition Board, Ghana (2014). Accreditation Documents. Retrieved on 10th December 2014 from $\mathrm{http}: / /$ nab.gov.gh/web3/2014-08-13-14-37-14

Niu, S. X., \& Tienda, M. (2008). Choosing colleges: Identifying and modeling choice sets. Social Science Research, 37(2), 416-433. http://dx.doi.org/10.1016/j.ssresearch.2007.06.015

Patrick, H. A. (2008). Psychological contract and employment relationship. The Icfai University Journal of Organizational Behavior, 7(4), 7-24.

Paulsen, M. B., \& St John, E. P. (2002). Social class and college costs: Examining the financial nexus between college choice and persistence. The Journal of Higher Education, 73(2), 189-236. http://dx.doi.org/10.1353/jhe.2002.0023

Perna L.W. (2006). Studying College Access and Choice, In Smart J.C. (ed.), Higher Education: Handbook of Theory and Research, XXI, 99-157, 2006Springer

Potter, J. (2013). Beyond access: Student perspectives on support service needs in distance learning. Canadian Journal of University Continuing Education, 24(1). 59-82.

Price, I. F., Matzdorf, F., Smith, L., \& Agahi, H. (2003). The impact of facilities on student choice of university. Facilities, 21(10), 212-222. http://dx.doi.org/10.1108/02632770310493580

Robbins, S. B., Lauver, K., Le, H., Davis, D., Langley, R., \& Carlstrom, A. (2004). Do psychosocial and study skill factors predict college outcomes? A meta-analysis. Psychological bulletin, 130(2), 261. http://dx.doi.org/10.1037/0033-2909.130.2.261

Rumble, G. (2000). Student support in distance education in the 21st century: Learning from service management. Distance Education, 21(2), 216-235. http://dx.doi.org/10.1080/0158791000210202

Sidin, S. M., Hussin, S. R., \& Soon, T. H. (2003). An exploratory study of factors influencing the college choice decision of undergraduate students in Malaysia. Asia Pacific Management Review, 8(3), 259-280.

Simões, C., \& Soares, A. M. (2010). Applying to higher education: information sources and choice factors. Studies in Higher Education, 35(4), 371-389. http://dx.doi.org/10.1080/03075070903096490

Terenzini, P. T., Cabrera, A. F., \& Bernal, E. M. (2001). Swimming against the tide: The poor in American higher education. College Board Research Report, No. 2001-1, 1-52.

University of Education, Winneba Basic Statistics (2013). University Publications Unit.

Vrontis, D., Thrassou, A., \& Melanthiou, Y. (2007). A contemporary higher education student-choice model for developed countries. Journal of Business Research, 60(9), 979-989. http://dx.doi.org/10.1016/j.jbusres.2007.01.023

Wilkins, S., Shams, F., \& Huisman, J. (2013). The decision-making and changing behavioural dynamics of potential higher education students: the impacts of increasing tuition fees in England. Educational Studies, 39(2), 125-141. http://dx.doi.org/10.1080/03055698.2012.681360

Yamane, T. (1967). Statistics: an introductory analysis. New York: Harper and Row. 